\title{
Mating behavior differences in monogamous and polygamous sympatric closely related species Mus musculus and Mus spicilegus and their role in behavioral precopulatory isolation
}

\begin{abstract}
Alexander V. Ambaryan, Vera V. Voznessenskaya \& Elena V. Kotenkova*
ABSTRACT. Closely related species with different mating system may be the most suitable model taxa for studies aimed to highlight the cause formation of species-specific peculiarities of sexual behavior and behavioral mechanisms of precopulatory isolation. The current study aimed to clarify the role of the mating system and lifestyle, including ecology features, in patterning of behavioral activities during mating, as well as the role of behavioral patterns in the precopulatory isolation of closely related Mus taxa. Test subjects were closely related sympatric species: polygynous/promiscuous $M$. musculus and presumably monogamous M. spicilegus, reproductively isolated in nature. Dyadic encounters of male and receptive female were conducted in clear chambers and the behavior was recorded by means of video camera. Sexual behavior, culminating in ejaculation, was observed in conspecific dyadic encounters only; it occurred more frequently and with longer duration in males of M. spicilegus, than in males of M. musculus. In conspecific encounters, males of $M$. spicilegus exhibited a higher level of affiliative behavior than females. In both species total frequency and duration of aggressive behavior was higher in females compared to males. In heterospecific dyadic encounters the behavioral pattern of males and females was strictly different from those in conspecific encounters, and the elements of aggressive behavior prevailed. We demonstrated that not only the pattern of sexual behavior is important for reproductive isolation, but also all types of behavioral interactions preceded copulation. In Mus species different stereotypes of mating behavior during the encounter of potential sexual partners can prevent successful copulation and may be associated with mating system.
\end{abstract}

How to cite this article: Ambaryan A.V., Voznessenskaya V.V., Kotenkova E.V. 2019. Mating behavior differences in monogamous and polygamous sympatric closely related species Mus musculus and Mus spicilegus and their role in behavioral precopulatory isolation // Russian J. Theriol. Vol.18. No.2. P.67-79. doi: 10.15298/rusjtheriol.18.2.01

KEY WORDS: sexual behavior, Mus musculus, Mus spicilegus, mating system, monogamy, precopulatory isolation.

AlexanderV. Ambarian [aambaryan@gmail.com], A.N. Severtsov Institute of Ecology and Evolution RAS, Leninskiy prospect 33, Moscow 119071, Russia; Vera V.Voznessenskaya [veravoznessenskaya@gmail.com], A.N. SevertsovInstitute of Ecology and Evolution RAS, Leninskiy prospect 33, Moscow 119071, Russia; Elena V. Kotenkova [evkotenkova@, yandex.ru], A.N. Severtsov Institute of Ecology and Evolution RAS, Leninskiy prospect 33, Moscow 119071, Russia.

\section{Различия поведения при спаривании у симпатрических моногамного и полигамного близкородственных видов Mus musculus, Mus spicilegus и их роль в формировании поведенческой прекопуляционной изоляции}

\author{
А.В. Амбарян, В.В. Вознесенская, Е.В. Котенкова
}

РЕЗЮМЕ. Близкородственные виды с разной системой спариваний являются наиболее подходящими модельными таксонами для исследований, направленных на выявление причин формирования видоспецифических особенностей полового поведения и поведенческих механизмов прекопуляционной изоляции. Целью исследования было выяснение роли системы спаривания и образа жизни, включая экологические особенности, в формировании паттернов поведения во время спаривания, а также роли поведенческих паттернов в прекопуляционной изоляции близкородственных таксонов Mus. Объектами исследования были близкородственные симпатрические и репродуктивно изолированные в природе виды: полигинный / промискуитетный M. musculus и предположительно моногамный $M$. spicilegus. Парные ссаживания самцов и самок в состоянии эструса проводили в прозрачных камерах,

\footnotetext{
* Corresponding author.
} 
и их поведение записывалось с помощью видеокамеры. Половое поведение, кульминацией которого является эякуляция, наблюдалось только в конспецифических ссаживаниях и проявлялось чаще и с большей продолжительностью у самцов M. spicilegus, чем у самцов M. musculus. В конспецифических ссаживаниях самцы M. spicilegus проявляли более высокий уровень аффилиативного поведения, чем самки. У обоих видов общая частота и продолжительность агрессивного поведения были выше у самок по сравнению с самцами. В гетероспецифических ссаживаниях особенности поведения самцов и самок резко отличались от таковых в конспецифических ссаживаниях, преобладали элементы агрессивного поведения. Мы показали, что не только паттерны полового поведения важны для репродуктивной изоляции, но также и все типы поведенческих взаимодействий, предшествующих копуляции. У видов Mus различные стереотипы поведения при спаривании во время встречи с потенциальными половыми партнерами могут препятствовать успешному спариванию и могут быть связаны с системой спариваний.

КЛЮЧЕВЫЕ СЛОВА: половое поведение, Mus musculus, Mus spicilegus, система спариваний, моногамия, прекопуляционная изоляция.

Closely related species with different mating system may be the most suitable model taxa for studies aimed to highlight the cause formation of species-specific peculiarities of sexual behavior. In accordance with current point of view, behavior that immediately precedes and follows mating bout, is likely to be involved in coordinating male-female interactions (Beach, 1976), as well as establishing the succession and temporal components of different parts of the mating cycles (Stopka \& Macdonald, 1998, 1999). Additionally, in monogamous species optimal behavioral patterns may also require activities associated with assuring male parental investment and pair bond maintenance. Sexual activities may reinforce the willingness of the male to remain with the family (Witt et al., 1988, 1990), thus it may be one of the factors involved in partner preferences and subsequent social bonds formation (Williams et al., 1992). It has been reported that in monogamous prairie vole (Microtus ochrogaster Wagner, 1842) cohabitation and accompanied events associated with mating or estrous induction, facilitate the onset of partner preferences (Williams et al., 1992). In addition, the social history of a pair may regulate the duration or pattern of reproductive behavior (Witt et al., 1990).

It may be assumed that affiliative behavior patterns (including frequency and duration of approaching, spending time in contact, following, grooming, etc.) that precede and prepare consecutive mating bouts depend on the type of mating system. In sexual context males of monogamous species of mammals may display affiliative behavior relatively longer and with greater frequency than males of polygynous species, which could lead to lengthening of the copulatory bout and to strengthening of the pair bond (Witt et al., 1988, 1990). However, relatively longer duration of such a behavior may be simply considered as the result of a long term coordinated activities between monogamous sexual partners. Higher level of affiliative behavior may be considered as a result of mate guarding, as it involves the close following of males to receptive females (Manno et al., 2007; Manno \& Dobson, 2008; Schubert et al., 2009).

The species of microtine rodents, which exhibit diverse social organizations, have been used as a model group for study different aspects of behavior, neurobiological mechanisms of pair bonding, bond disruption, and social buffering in monogamous and polygamous species (Young et al., 2011; Johnson \& Young, 2015; Lieberwirth \& Wang, 2016). Comparative studies of other monogamous and polygamous closely related species of small rodents are sparse.

Superspecies complex Mus musculus sensu lato includes species with different mating systems. The mating system of commensal taxa (Mus musculus L., 1758, Mus domesticus Schwarz et Shwarz, 1943) generally may be described as polygynous (Crowcroft, 1955; Mackintosh, 1981; Wolf, 1985; Sokolov et al., 1990b; Krasnov \& Chochlova, 1994; Kotenkova \& Munteanu, 2006), while wild living species M. spicilegus Petenye, 1882 has presumably monogamous breeding system (Dobson \& Baudoin, 2002; Patris et al., 2002; Poteaux et al., 2008). According to various estimates, the divergence of commensal and wild living species occurred 1-2 million years ago (Mezhzherin, 1994; Chevret et al., 2005). $M$. musculus and M. spicilegus are sympatric, hybrids are not found in nature (Sokolov et al., 1990b). Males and females of these species were crossed under laboratory conditions, and their $F_{1}$ and $F_{2}$ hybrids are viable and fertile (Bulatova et al., 1986). The social organization of natural and semi-natural populations in commensal taxa has pronounced plasticity and varies widely with regions or size of enclosure (Crowcroft, 1954, 1955; Crowcroft \& Rowe, 1963; Lloyd, 1975; Lidicker, 1976; Singleton \& Hay, 1983; Sokolov et al., 1990b; Krasnov \& Chochlova, 1994; Walkowa et al., 1998). At low population density males defend individual territories, but they form dominance hierarchies at high densities (Davis, 1958). Nevertheless, in all cases M. musculus and $M$. domesticus preserve polygynous mating system.

Mound-building mice bred seasonally from March to October (Naumov, 1940; Sokolov et al., 1990b, 1998). A distinctive character of $M$. spicilegus is its grain-hoarding activity. After a period of reproduction from spring to late summer, when adult breeding pairs produce a few litters in simply designed burrows, groups of 4-14 mice construct special mounds (kurgans) in which to store 
food and live for the winter (Naumov, 1940; Pisareva, 1948; Sokolov et al., 1990b). Virtually nothing is known about the behavioral interactions of males and females in nature, while under laboratory conditions they exhibit typical behavior of monogamous species. Experimental data showed monogamy in mound-building mice within the otherwise polygynous/promiscuous genus $M u s(\mathrm{~Pa}-$ tris \& Baudoin, 1998). Females of mound-building mice have consistently preferred a familiar over an unfamiliar male. Moreover, they refused to copulate with unfamiliar males (Patris \& Baudoin, 1998, 2000). In contrast, two choice preference tests showed that estrous females of commensal and outdoor populations of $M$. domesticus investigated unfamiliar males more than familiar ones (Frynta et al., 2010). M. spicilegus female, living in multifemale groups reproduce less successfully (Gouat $\&$ Feron, 2005). Males of this species invest significantly in warming the young, retrieving stray pups, and other forms of the parental care (Patris \& Baudoin, 2000) which reduces inter-litter intervals (Feron \& Gouat, 2007). Observations of stable male-female associations within enclosures as well as physiological data clearly suggest formation of social pair bonding in this species (Sokolov et al., 1990b; Baudoin et al., 2005, Bardet et al., 2007). Unfamiliar M. spicilegus are not able to form stable groups with a hierarchical structure of relationships. In M. spicilegus groups, maintained in cages of 1 $\mathrm{m}^{2}$, subordinate males and females usually die in 10-15 days after the start of group formation. Then the dominant pair started to breed. The male and female defended the territory and attacked strangers regardless of their gender (Sokolov et al., 1990b). Monogamous type of mating system may be suggested as a typical in mound-building mouse based on the evidences of monogamy observed under semi-natural conditions (Dobson \& Baudoin, 2002; Patris et al., 2002; Poteaux et al., 2008).

Differences in mating systems may have meaningful consequences in the communication of heterospecific potential partners in closely related species forming one of the precopulatory isolating mechanisms. According to numerous studies, mate choice of conspecifics relies on species-specific cues and behavior is an important mechanism of precopulatory isolation in closely related species in different taxonomic groups of animals (Chatterjee \& Singh, 1989; Verrell, 1999; Ptacek, 2000; Smadja \& Butlin, 2009; Kotenkova, 2014). Differences in copulatory behavior of closely related species are the most important (Chatterjee \& Singh, 1989). Though there are exceptions. For example, for some species of vole genus Microtus differing patterns of male copulatory behavior are not effective in maintaining of reproductive isolation among sympatric species, but in the other ones these differences are the most important (Zorenko $\&$ Malygin, 1984). According to one of the approaches, the features of sexual behavior of representatives of closely related taxa could be used to clarify its taxonomic status and phylogenetic relationships with other species (Zorenko \& Atanasov, 2017, 2018).

Sexual behavior of laboratory mice has been described and the existence of quantitative differences in copulatory behavior among inbred strains of mice has been established (McGill, 1962; Abeelen, 1966; Levine et al., 1966; McGill \& Ranson, 1968; Mosig \& Dewsbury, 1976). The wild house mouse appeared to be much more extreme in certain of quantitative aspects of copulatory behavior than most inbred strains (Estep et al., 1975). Description of different behavioral patterns including sexual behavior of the house mice has been reported (Grant \& Mackintosh, 1963; Mackintosh, 1981; Sokolov et al., 1990b). Mating behavior of M. domesticus under natural conditions also was investigated (Hurst, 1986).

The current study aimed to clarify the role of the mating system and lifestyle, including ecology features, in patterning of behavioral activities during mating. Specifically, the investigation was focused on the interrelation between type of mating system and lifestyle on the one hand, and appearance of affiliative, copulatory and aggressive behavior during reproductive activity on the other hand in closely related species as well as on the role of these behavioral patterns in the precopulatory isolation of closely related Mus taxa. Test subjects were closely related sympatric $M$. musculus and $M$. spicilegus, these species are reproductively isolated in nature.

\section{Material and methods}

\section{Test subjects}

This work was carried out using the collection of animals from the Living Collection of Wild Mammalian Species of the Common Science Center (A.N. Severtsov Institute of Ecology and Evolution, Russian Academy of Sciences). Experimental crosses of house mice were performed in the vivarium at the Chernogolovka Scientific and Experimental Center (A.N. Severtsov Institute of Ecology and Evolution, Russian Academy of Sciences).

Test subjects were 46 males and 49 females of $M$. musculus trapped in Moscow as well as laboratory-reared individuals ( $\mathrm{F}_{1}-\mathrm{F}_{5}$ generations); 29 males and 22 females of $M$. spicilegus from Crimea Peninsula (collected from mounds and $F_{1}$ reared in laboratory). Males were housed singly; females were kept in groups of three-four individuals in standard plastic cages measuring $29 \times 19$ $\times 13 \mathrm{~cm}$ at least during 10 days prior the experiments. All animals were kept on standard natural diet for mice (oats, grains, sunflower seeds, vegetables) ad libitum.

The colony room was maintained on natural lightdark cycle at a room temperature of $22 \pm 4^{\circ} \mathrm{C}$.

\section{Apparatus}

Behavioral tests were conducted in clear chambers $(50 \times 25 \times 30 \mathrm{~cm})$ that were divided by plastic partition with small round holes into two equal compartments.

\section{Procedure}

The procedure of the experiments has been described in detail earlier (Ambaryan et al., 2015). Here we present a brief description. Conspecific dyadic encounters of 
male and estrous female were conducted from April to September. Total number of tests was 50 (male M. musculus $\times$ female M. musculus, $n=15$; male M. spicilegus $\times$ female $M$. spicilegus, $n=15$; male $M$. musculus $\times$ female M. spicilegus, $n=10$; male $M$. spicilegus $\times$ female $M$. musculus, $n=10$ ). Before experiment male and female have been adapted to experimental chamber for 6 hours The experimental chamber was divided into two equal compartments. There was a female in one compartment, and a male was in another. Test started with removal of the partition of the experimental chamber. Standard duration of the test was 90 minutes if patterns of sexual behavior were initiated within the first 30 minutes. Estrous phase of female reproductive cycle was determined by means of vaginal smears (Nelson et al., 1982; Sokolov et al., 1990a).

Behavioral testing was carried out in separate room at dark phase between $22.00 \mathrm{~h}$ and $02.00 \mathrm{~h}$. During behavioral testing one red $40-\mathrm{W}$ bulb located near the chamber was turned on.

\section{Measures}

Behavior of the subjects was recorded by means of video camera Sony Digital. Data analysis was made by means of Observer Video-Pro, Version 4.1, professional system for collection, analysis, presentation and management of observational data (Noldus, The Netherlands). According to software guide, each behavioral element was assigned a specific keyboard key combination.

Behavioral elements were divided into three classes (Dewsbury et al., 1979; Mackintosh, 1981; Kotenkova et al., 1989a): sexual behavior (attempts of mounts, mounts with intromissions, mounts without intromissions, mounts with intromissions and thrusts, lordosis, genital lock, ejaculations); aggressive behavior (fighting, attacks, threat posture, reciprocal upright, pushing, submissive posture, «pendulum» movements, circle round the partner, sideways posture, jumping with pushing the partner, jumping over the partner, boxing, chase, rattle of the tail) and affiliative behavior (naso-nasal, naso-anal contacts, investigation of different parts of the partners body, following, crawling over partner, approaching, grooming of the partner, exposure for grooming, crowding, crawling to partner, sniffing). All behavioral elements data (except sexual behavior elements, sexual behavior relational parameters data, crowding and grooming of the partner) were pooled into total frequency and duration of two behavioral classes: affiliative behavior and aggressive behavior.

\section{Statistical analysis}

Conspecific (pairwise) comparisons between conand heterospecific females and males were performed by using nonparametric Mann-Whitney U-Test ("SigmaPlot for Windows, ver. 14.0"). We accepted the level of significance as $p<0.05$, in all tables we presented medians.

\section{Results}

Only in conspecific dyadic encounters of males and females in both $M$. musculus and M. spicilegus we observed all the characteristic elements of sexual behavior ended up with ejaculation. In heterospecific dyadic encounters behavioral pattern of males and females was strictly different from those in conspecific encounters, and the elements of aggressive behavior prevailed. Only one male $M$. musculus in heterospecific encounters demonstrated attempts of mounts and mounts without intromissions. Taking this into consideration, statistical analysis for heterospecific encounters was performed separately.

\section{Conspecific encounters}

\section{Aggressive behavior}

In both species, total frequency and duration of aggressive behavior was higher in females compared to males (Table 1). Males of M. spicilegus exhibited this type of behavior more frequently and longer than males of M. musculus (Table 1). Whereas females of M. musculus demonstrated more frequently and longer aggression toward conspecific males than $M$. spicilegus females (Table 1).

Table 1. Medians of frequency and duration of aggressive behavior in males and females of Mus spicilegus and M. musculus in conspecific encounters.

\begin{tabular}{|c|c|c|c|c|c|c|}
\hline \multirow[b]{2}{*}{ Paired comparisons } & \multicolumn{3}{|c|}{ Frequency of behavior } & \multicolumn{3}{|c|}{ Duration of behavior } \\
\hline & Median & $\begin{array}{l}\text { Mann-Whit- } \\
\text { ney U-test }\end{array}$ & $\begin{array}{l}\text { level of signif- } \\
\text { icance, } p\end{array}$ & $\begin{array}{l}\text { M e dia n } \\
\text { (seconds) }\end{array}$ & $\begin{array}{l}\text { Mann-Whit- } \\
\text { ney U-test }\end{array}$ & $\begin{array}{l}\text { level of signifi- } \\
\text { cance, } p\end{array}$ \\
\hline $\begin{array}{l}1 \text { - males } M . \text { spicilegus, } \\
2 \text { - females } M . \text { spicilegus }\end{array}$ & $\begin{array}{l}1-11 \\
2-44\end{array}$ & 40 & $<0.01$ & $\begin{array}{c}1-4 \\
2-20\end{array}$ & 53 & $<0.05$ \\
\hline $\begin{array}{l}1 \text { - males } M . \text { musculus, } \\
2 \text {-females } M . \text { musculus }\end{array}$ & $\begin{array}{l}1-1 \\
2-120\end{array}$ & 5 & $<0.001$ & $\begin{array}{c}1-1 \\
2-45\end{array}$ & 8 & $<0.001$ \\
\hline $\begin{array}{l}1 \text { - males } M . \text { spicilegus, } \\
2 \text { - males } M . \text { musculus }\end{array}$ & $\begin{array}{l}1-11 \\
2-1\end{array}$ & 25 & $<0.001$ & $\begin{array}{l}1-4 \\
2-1\end{array}$ & 34 & $<0.01$ \\
\hline $\begin{array}{l}1 \text { - females } M . \text { spicilegus, } \\
2 \text { - females } M . \text { musculus }\end{array}$ & $\begin{array}{l}1-44 \\
2-120\end{array}$ & 40 & $<0.01$ & $\begin{array}{l}1-20 \\
2-45\end{array}$ & 55 & $<0.05$ \\
\hline
\end{tabular}


Table 2. Medians of frequency and duration of affiliative behavior in males and females of Mus spicilegus and M. musculus in conspecific encounters.

\begin{tabular}{|c|c|c|c|c|c|c|}
\hline \multicolumn{7}{|c|}{ Summarized elements of affiliative behavior } \\
\hline \multirow[b]{2}{*}{ Paired comparisons } & \multicolumn{3}{|c|}{ Frequency of behavior } & \multicolumn{3}{|c|}{ Duration of behavior } \\
\hline & Median & $\begin{array}{l}\text { Mann-Whit- } \\
\text { ney U-test }\end{array}$ & $\begin{array}{l}\text { level of signif- } \\
\quad \text { icance, } p\end{array}$ & $\begin{array}{l}\text { Median } \\
\text { (seconds) }\end{array}$ & $\begin{array}{l}\text { Mann-Whit- } \\
\text { ney U-test }\end{array}$ & $\begin{array}{l}\text { level of signifi- } \\
\quad \text { cance, } p\end{array}$ \\
\hline $\begin{array}{l}1 \text { - males } M . \text { spicilegus, } \\
2 \text { - females } M . \text { spicilegus }\end{array}$ & $\begin{array}{l}1-994 \\
2-696\end{array}$ & 37 & $<0.01$ & $\begin{array}{l}1-1377 \\
2-792\end{array}$ & 47 & $<0.01$ \\
\hline $\begin{array}{l}1 \text { - males M. musculus, } \\
2 \text {-females M. musculus }\end{array}$ & $\begin{array}{l}1-546 \\
2-379\end{array}$ & 67 & NS & $\begin{array}{l}1-919 \\
2-889\end{array}$ & 105 & NS \\
\hline $\begin{array}{l}1 \text { - males } M . \text { spicilegus, } \\
2 \text { - males M. musculus }\end{array}$ & $\begin{array}{l}1-994 \\
2-546\end{array}$ & 2 & $<0.001$ & $\begin{array}{c}1-1377 \\
2-919\end{array}$ & 64 & $<0.05$ \\
\hline $\begin{array}{l}1 \text { - females } M . \text { spicilegus, } \\
2 \text { - females M. musculus }\end{array}$ & $\begin{array}{l}1-696 \\
2-379 \\
\end{array}$ & 40.5 & $<0.01$ & $\begin{array}{l}1-792 \\
2-889 \\
\end{array}$ & 100 & NS \\
\hline \multicolumn{7}{|c|}{ Crowding and grooming } \\
\hline $\begin{array}{l}1 \text { - males M. spicilegus, } \\
2 \text { - females } M . \text { spicilegus }\end{array}$ & $\begin{array}{l}1-33 \\
2-9\end{array}$ & 60 & $<0.05$ & $\begin{array}{l}1-199 \\
2-32\end{array}$ & 50 & $<0.05$ \\
\hline $\begin{array}{l}1 \text { - males M. musculus, } \\
2 \text {-females M. musculus }\end{array}$ & $\begin{array}{l}1-20 \\
2-3\end{array}$ & 69 & NS & $\begin{array}{l}1-164 \\
2-12\end{array}$ & 58 & $<0.05$ \\
\hline $\begin{array}{l}1 \text { - males } M . \text { spicilegus, } \\
2 \text { - males } M . \text { musculus }\end{array}$ & $\begin{array}{l}1-33 \\
2-20\end{array}$ & 75 & NS & $\begin{array}{l}1-199 \\
2-164\end{array}$ & 112 & NS \\
\hline $\begin{array}{l}1 \text { - females } M . \text { spicilegus, } \\
2 \text { - females } M . \text { musculus }\end{array}$ & $\begin{array}{l}1-9 \\
2-3 \\
\end{array}$ & 63 & $<0.05$ & $\begin{array}{l}1-32 \\
2-12 \\
\end{array}$ & 79 & NS \\
\hline
\end{tabular}

\section{Affiliative behavior}

Males of M. spicilegus exhibited a higher level of affiliative behavior than conspecific females. This concerns frequency and duration of affiliative behavior (Table 2). There were no significant sexual differences in M. musculus (Table 2). Total frequency and duration of all elements of affiliative behavior was significantly higher in males of M. spicilegus, than in males of $M$. musculus (Table 2). Affiliative behavior occurs more frequently in $M$. spicilegus females than in females of M. musculus, but there were no interspecific significant differences in duration for this type of behavior (Table 2). Nevertheless, males of $M$. spicilegus exhibited summarized mutual grooming and crowding (sitting together) more frequently and longer than conspecific females. Duration of that type of behavior was also longer in $M$. musculus males than in conspecific females. At the same time these behavioral patterns occurred in M. spicilegus males more frequently than in males of $M$. musculus (Table 2).

\section{Sexual behavior}

Sexual behavior occurs more frequently and with longer duration in males of M. spicilegus, than in males of M. musculus. Specifically, this concerns frequency of ejaculation as well as total duration of sexual behavior in males. Median of frequency of ejaculation was four times higher in $M$. spicilegus males, than in males of M. musculus (Fig. 1). Total duration of sexual behavior was also nearly twice longer in $M$. spicilegus males than in males of M. musculus (Fig. 2). Frequency of mounts without intromission, mounts with intromission, genital lock and mounts with intromissions and thrusts was higher in $M$. spicilegus males than in males of $M$. musculus either (Table 3). The number of thrusts per one ejaculation and per one intromission was significantly higher in M. musculus males (Figs. 3, 4).

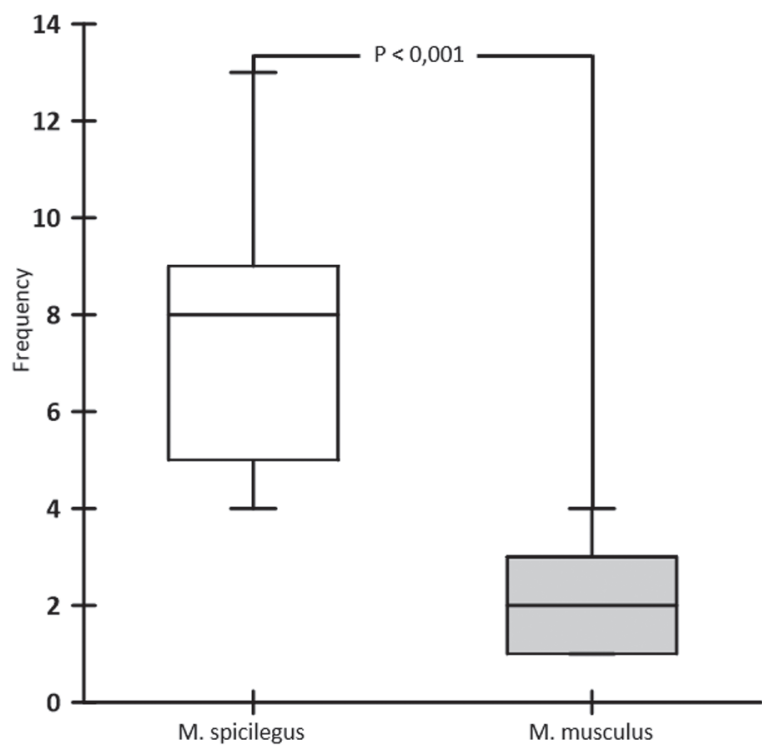

Fig. 1. Medians of frequency of ejaculation in males of Mus spicilegus and M. musculus (percentile 5-95\%).

Legends for Figs. 1-4. - median, $\square-25-75 \%$ interquartile range, $\top$ - percentiles. 
Table 3. Medians of frequency of sexual behavior elements in Mus musculus and M. spicilegus males.

\begin{tabular}{|l|c|c|c|c|}
\hline Behavioral elements & $\begin{array}{c}\text { Median of behavioral } \\
\text { element in M. spicile- } \\
\text { gus males }\end{array}$ & $\begin{array}{c}\text { Median of behavioral } \\
\text { element in M. musculus } \\
\text { males }\end{array}$ & $\begin{array}{c}\text { Mann-Whitney } \\
\text { U-test }\end{array}$ & level of significance, $p$ \\
\hline attempts of mounts & 60 & 28 & 72 & NS \\
\hline genital lock & 2 & 0 & 64.5 & $<0.05$ \\
\hline $\begin{array}{l}\text { mounts without in- } \\
\text { tromissions }\end{array}$ & 32 & 12 & 68 & $<0.01$ \\
\hline $\begin{array}{l}\text { mounts with intro- } \\
\text { missions }\end{array}$ & 1 & 0 & 39.5 & $<0.05$ \\
\hline $\begin{array}{l}\text { mounts with intro- } \\
\text { missions and thrusts }\end{array}$ & 26 & 12 & $<0.01$ \\
\hline
\end{tabular}

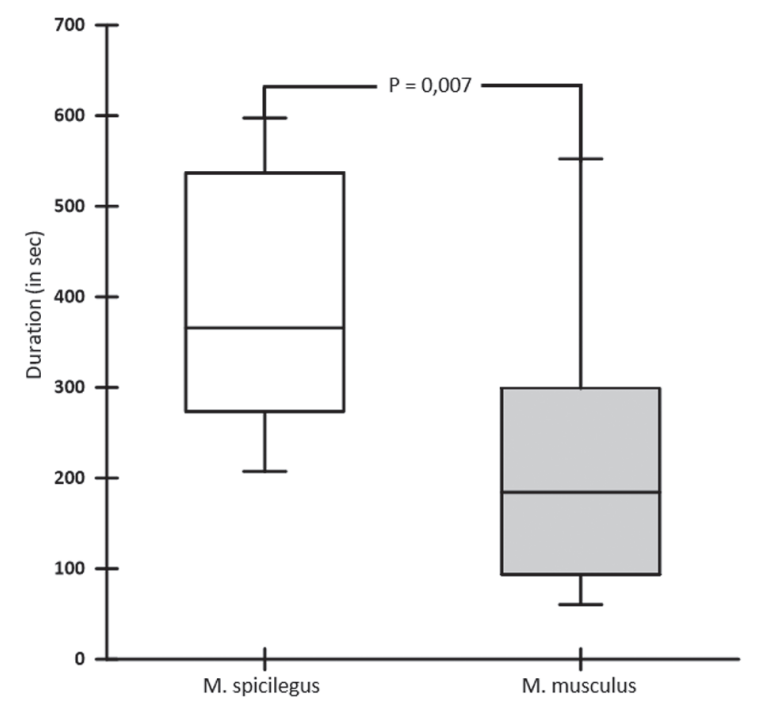

Fig. 2. Medians of duration of sexual behavior in males of Mus spicilegus and M. musculus (percentile 10-90\%).

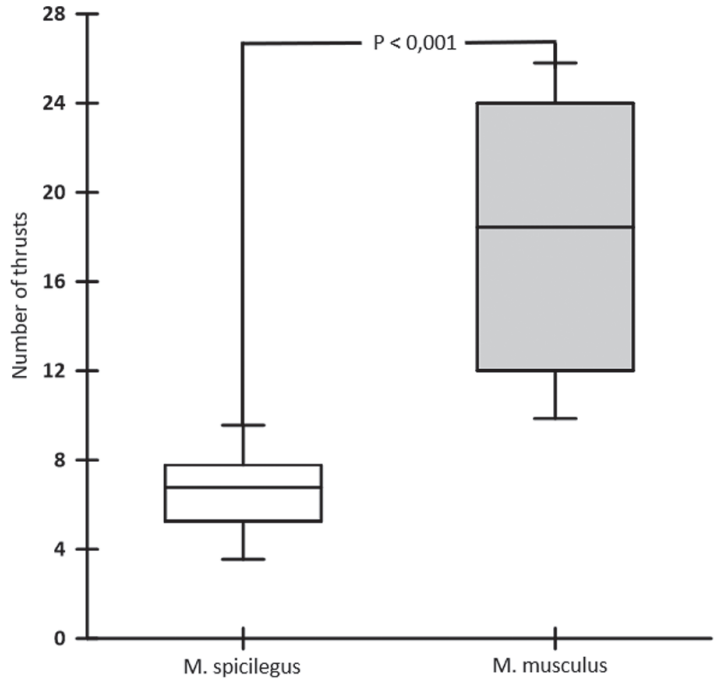

Fig. 3. Medians of number of thrusts per one intromission in males of Mus spicilegus and M. musculus (percentile 10-90\%).

\section{Heterospecific encounters}

\section{Aggressive behavior}

In encounters of males of $M$. musculus and females of M. spicilegus, females of mound building mice exhibited aggressive behavior more frequently than their heterospecific partners (Table 4). At the same time, duration of that type of behavior did not differ significantly (Table 4). No significant differences between partners in duration and frequency of aggressive behavior were registered in encounters of females of $M$. musculus and males of $M$. spicilegus. During encounters with heterospecific sexual partner males of $M$. spicilegus demonstrated aggressive behavior more frequently than males of $M$. musculus (Table 4). Though differences in duration of that type of behavior were not significant (Table 4). Females of $M$. spicilegus during encounters with heterospecific sexual partner also exhibited aggressive behavior frequently, but not longer than females of M. musculus (Table 4).

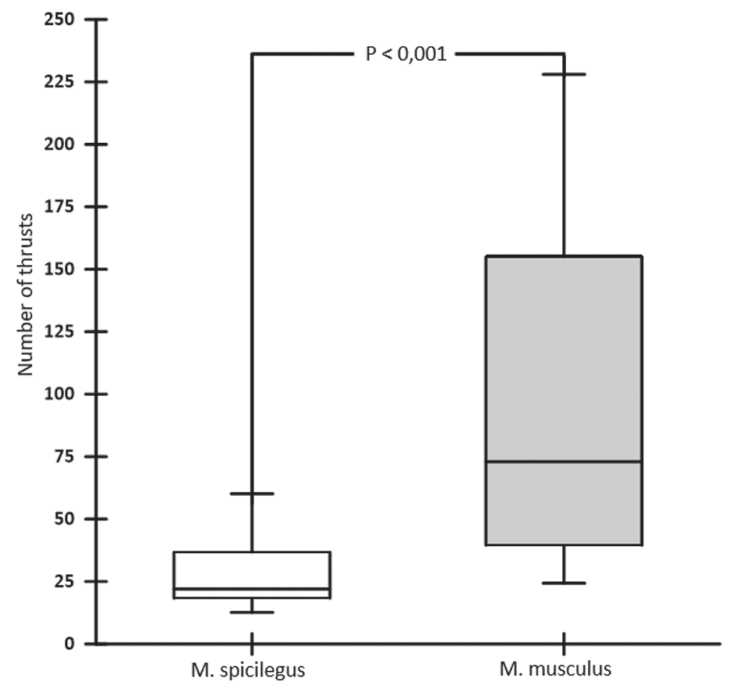

Fig. 4. Medians of number of thrusts per one ejaculation in males of Mus spicilegus and M. musculus (percentile 10-90\%). 
Table 4. Medians of frequency and duration of aggressive behavior in males and females of Mus spicilegus and M. musculus in heterospecific encounters.

\begin{tabular}{|l|c|c|c|c|c|c|}
\hline \multicolumn{1}{|c|}{ Paired comparisons } & \multicolumn{3}{|c|}{ Frequency of behavior } & \multicolumn{3}{c|}{ Duration of behavior } \\
\cline { 2 - 7 } & Median & $\begin{array}{c}\text { Mann-Whit- } \\
\text { ney U-test }\end{array}$ & $\begin{array}{c}\text { level of sig- } \\
\text { nificance, } p\end{array}$ & $\begin{array}{c}\text { Median } \\
\text { (seconds) }\end{array}$ & $\begin{array}{c}\text { Mann-Whit- } \\
\text { ney U-test }\end{array}$ & $\begin{array}{c}\text { level of signifi- } \\
\text { cance, } p\end{array}$ \\
\hline $\begin{array}{l}1-\text { males M. spicilegus, } \\
2-\text { females M. musculus }\end{array}$ & $\begin{array}{c}1-102.5 \\
2-70.5\end{array}$ & 34.5 & NS & $\begin{array}{c}1-54 \\
2-74\end{array}$ & 33 & NS \\
\hline $\begin{array}{l}1-\text { males M. musculus, } \\
2 \text {-females M. spicilegus }\end{array}$ & $\begin{array}{c}1-52 \\
2-239\end{array}$ & 11.5 & $<0.01$ & $\begin{array}{c}1-159 \\
2-269\end{array}$ & 36 & $\mathrm{NS}$ \\
\hline $\begin{array}{l}1-\text { males M. spicilegus, } \\
2-\text { males M. musculus }\end{array}$ & $\begin{array}{c}1-102.5 \\
2-52\end{array}$ & 23 & $<0.05$ & $\begin{array}{c}1-54 \\
2-159\end{array}$ & 33 & $\mathrm{NS}$ \\
\hline $\begin{array}{l}1-\text { females M. spicilegus, } \\
2-\text { females M. musculus }\end{array}$ & $\begin{array}{c}1-239 \\
2-70.5\end{array}$ & 18 & $<0.05$ & $\begin{array}{c}1-269 \\
2-74\end{array}$ & 28 & $\mathrm{NS}$ \\
\hline
\end{tabular}

\section{Affiliative behavior}

In all types of heterospecific encounters of males and females of two species frequency and duration of affiliative behavior did not differ significantly between potential sexual partners (Table 5). Differences between males of M. spicilegus and M. musculus in frequency and duration of affiliative behavior were not significant (Table 5). At the same time, females of $M$. spicilegus exhibited this type of behavior less frequently than females of $M$. musculus, although for duration of affiliative behavior this ratio was not complied (Table 5). Grooming observed only once, when $M$. musculus male groomed $M$. spicilegus female.

\section{Discussion}

Various evolutionary aspects concerning the mating systems are discussed in a number of reviews (Emlen \& Oring, 1977; Dewsbury, 1987; Brotherton \& Komers, 2003; Waterman, 2007; Dobson et al., 2010). In our study we examined the extent of difference between mating behaviors in two closely related taxa of house mice and how these behavioral differences may be linked to diversity in their mating systems and lifestyle, including ecology features. In general, during conspecific encounters motor patterns of copulatory behavior as well as motor patterns of entire behavioral interactions were very similar in those closely related sympatric species. At the same time, drastic differences were observed in frequency and duration of sexual behavior between wild living M. spicilegus and commensal M. musculus.

According to a number of data, male sperm competition (and, consequently, selection directed to enhancing sperm competitiveness and frequency characteristics of sexual behavior) is determined by the male's ability to monopolize females to a large extent (Clutton-Brock \& Isvaran, 2006; Isvaran \& Clutton-Brock, 2007). Yet recently it was considered that monogamy was one of the reliable ways of monopolization. Indeed, in case of monogamy, the male and female defend their territory from strangers together (Fitzgerald \& Madison, 1983; Getz et al., 1987). Stable pair bonding of sexual partners is another factor preventing the mating of the female with several males. Thus, the joint defense of the territory and stable pair bonding of sexual partners in monogamy can reduce the natural selection, aimed at enhancing of sperm competitiveness and the features of sexual behavior. Indeed, an analysis of the testes mass index in 133 mammalian species of different taxonomic

Table 5. Medians of frequency and duration of affiliative behavior in males and females of Mus spicilegus and M. musculus in heterospecific encounters.

\begin{tabular}{|l|c|c|c|c|c|c|}
\hline \multirow{2}{*}{ Paired comparisons } & \multicolumn{3}{|c|}{ Frequency of behavior } & \multicolumn{3}{c|}{ Duration of behavior } \\
\cline { 2 - 7 } & Median & $\begin{array}{c}\text { Mann-Whit- } \\
\text { ney U-test }\end{array}$ & $\begin{array}{c}\text { level of sig- } \\
\text { nificance, } p\end{array}$ & $\begin{array}{c}\text { Median } \\
\text { (seconds) }\end{array}$ & $\begin{array}{c}\text { Mann-Whit- } \\
\text { ney U-test }\end{array}$ & $\begin{array}{c}\text { level of signifi- } \\
\text { cance, } p\end{array}$ \\
\hline $\begin{array}{l}1-\text { males M. spicilegus, } \\
2-\text { females M. musculus }\end{array}$ & $\begin{array}{c}1-119.5 \\
2-240\end{array}$ & 26 & NS & $\begin{array}{c}1-163 \\
2-192\end{array}$ & 37 & NS \\
\hline $\begin{array}{l}1-\text { males M. musculus, } \\
2-\text { females M. spicilegus }\end{array}$ & $\begin{array}{c}1-352.5 \\
2-162\end{array}$ & 31 & NS & $\begin{array}{c}1-227 \\
2-140\end{array}$ & 31 & NS \\
\hline $\begin{array}{l}1-\text { males M. spicilegus, } \\
2-\text { males M. musculus }\end{array}$ & $\begin{array}{c}1-119.5 \\
2-352.5\end{array}$ & 30 & NS & $\begin{array}{c}1-163 \\
2-227\end{array}$ & 32 & NS \\
\hline $\begin{array}{l}1-\text { females M. spicilegus, } \\
2-\text { females M. musculus }\end{array}$ & \begin{tabular}{c}
$1-16$ \\
\hline
\end{tabular} & 23 & $<0.05$ & $\begin{array}{c}1-140 \\
2-192\end{array}$ & 36 & NS \\
\hline
\end{tabular}


groups showed that this indicator in monogamous species is lower relative to polygamous (Kenagy \& Trombulak, 1986), these findings were confirmed by a number of other investigations (Harcourt et al., 1981; Harvey \& Harcourt, 1984; Pitcher et al., 2005).

Closely related species of house mice do not fit into these experimental results, since the permissive monogamous species of $M$. spicilegus has the largest size and weight of testes compared to all other species of the Mus musculus sensu lato superspecies complex, including the polygamous M. musculus (Frynta et al., 2009; Montoto et al., 2011). These findings await rational explanations. Our data indicate that the frequency of ejaculations in $M$. spicilegus is significantly higher compared to M. musculus, which is inconsistent with the data obtained for some species of voles and other mammals. Multiple ejaculations are more effective in sperm- competition situation when males mate with a few females (Dewsbury, 1981), as vaginal plug is formed. The copulatory plugs inhibit the reproductive success of rival males (Mangels et al., 2016). Theory predicts an increased sperm allocation in response to an elevated risk of sperm competition, and male Mus domesticus instead ejaculate fewer sperm per ejaculate when mating in the presence of a rival male (Ramm \& Stockley, 2007). In predominantly monogamous species of voles and primates, number of ejaculations is usually less than in species with promiscuous or polyandric mating type (Dewsbury, 1987; Dixon, 2012; Zorenko, 2013).

However, a number of investigations evidence that monogamy does not guarantee - paternity unambiguity. For example, in monogamous and polygamous species of birds and mammals, the percentage of offspring originating from the father in a stable pair or the dominant male in a group, ranges from 0 to $40 \%$; this indicator does not depend on the mating system. Females could mate with other males when partners did not control their behavior (Roemer et al., 2001; Clutton-Brock \& Isvaran, 2006). Spatial-ethological structure of groupings and the spatial-temporal characteristics of the female grouping are key factors affecting the male's ability to control females and prevent them from mating with other males (Shuster \& Wade, 2003; Noordwijk \& Schaik, 2004). Regardless of the breeding system (monogamy or polygyny), the incidence of mating "on the side" grows in case of insufficient stability of the pair or group (Clutton-Brock et al., 1982).

Investigation of interspecific differences revealed that the size of the testes of predatory mammals did not depend on the mating system, but negatively correlated with the duration of the breeding season: the shorter it is, the larger the size of the testes (Iossa et al., 2008). According to the authors, the observed phenomenon may be due to estrous synchronization in a large number of females; that makes control by the males quite difficult. The same study revealed a clear correlation of phylogenetic relationships between species with the size of testes. The described interrelations could be one of the most influential factors for development of the stereotype of sexual behavior. Another cause of mating "on the side" may be an increase in the proportion of females in the breeding group regardless of the breeding system (Isvaran \& Clutton-Brock, 2007).

As already noted in the introduction, the spatial-ethological structure of the populations, the mating system and seasonality of reproduction in the synanthropic $M$. musculus and wild living $M$. spicilegus differ significantly. These differences may affect the competition of male sperm and, therefore, the stereotype of their sexual behavior. Social system of mound-building mice is characterized by pronounced seasonal cyclical changes. In the autumn, a group consisting of 6-12 young individuals (belonging to the last litters of one or two, probably neighboring pairs) builds a kurgan with feed reserves containing seeds of cultivated and weed plants, covering them from above with a thick layer of soil. Mice live in kurgans during all winter, they are protected from low temperatures and feed on stored seed (Naumov, 1940; Pisareva, 1948; Sokolov et al., 1990b). During this period, they do not breed; aggressive interactions between mice from the same mound are not observed, however both males and females are very aggressive towards individuals from other groups (Sokolov et al., 1988, 1990b). In the spring, mice move out of the mounds, at this time the density of their populations may be three times greater than in the subsequent summer, and the number of males may be as twice higher as number of females (Simeonovska-Nicolova, 2012). Whereas the females occupy individual home ranges near their mound, the males settle much further (Poteaux et al., 2008). Most likely, that resettlement followed by increased mortality, since the population density drops during summer breeding period. In late spring and in summer, the sex ratio reverses, and number of females prevails over males (Gouat et al., 2003; Poteaux et al., 2008; Simeonovska-Nicolova, 2012). During this period, home ranges of males could significantly overlap with ranges of several females (Hamar \& Sutova-Hamar, 1969; Kotenkova \& Munteanu, 2006), as well as with ranges of other males (Simeonovska-Nicolova, 2007, 2012).

Though numerous studies under laboratory and semi-natural conditions suggest the monogamous mating systems in mound-building mice (Sokolov et al., 1990b; Patris \& Baudoin, 1998, 2000; Dobson \& Baudoin 2002; Patris et al., 2002; Baudoin et al., 2005; Gouat \& Feron, 2005), the quantitative prevalence of females over males in the beginning of the breeding season contributes to optional polygyny. Under laboratory conditions, groups consisting of one male and two females, also breed, though less successfully than couples (Gouat $\&$ Feron, 2005). Optional polygyny may be one of the reasons for the natural selection aimed at improving the competitiveness of male sperm. By implication, this hypothesis is supported by observations of variability in the reproductive strategy in another monogamous species of rodents - the prairie vole Microtus ochrogaster. Population density of this species varies greatly, like in case of the mound-building mouse; up to $55 \%$ of males can form a pair bonding with one female, and males missing own individual range ("stray") can seek to mate with 
different females (Carter et al., 1995). Such a situation may occur at a high population density, when resident males could not prevent the entries of strangers into their territory. Approximately $25 \%$ of females of this species are promiscuous (Getz et al., 1987).

Such a deviation from the strictly monogamous mating system may be sufficient to maintain selection for increased competition for females and, thus, for the increased size of the testes (Heske \& Ostfeld, 1990). Indeed, the size of the testes in Microtus ochrogaster is quite comparable with that in promiscuous species of voles (M. montanus Peale, 1848, M. pennsylvanicus Ord, 1815, and $M$. breweri Baird, 1858) (Heske \& Ostfeld, 1990). Another factor contributing to the selection of male sperm for increasing competitiveness in mound-building mice may be a pronounced seasonality of reproduction, which leads to the synchronization of estrous in a significant number of females. It makes difficult for males to control their females as well as increases the probability for females to mate with other males. At the same time, in synanthropic species of house mice living in human buildings, the seasonality of breeding is not pronounced (Bronson, 1979; Pelikán, 1981; Carlsen, 1993). Therefore, males have the opportunity to mate with females, regardless of the season (although the intensity of reproduction may fluctuate seasonally). Perhaps year-round reproduction of synanthropic species of mice, helps to reduce the competition of males, and, as a result, negatively affect relative size of the testes, the quality of sperm and the number of ejaculations.

Since in monogamous mammals, such as prairie voles, sexual interactions and concomitant physiological changes may contribute to partner preferences formation and establishing of social pair bonding (Carter et al., 1988; Williams et al., 1992), we suppose that greater than in commensal species frequency of ejaculations in M. spicilegus males may be one of the mechanisms that promote monogamous pair formation in this species. The formation of pairs in M. spicilegus involves the process of habituation of partners to each other (Patris \& Baudoin, 1998). Probably the result of this habituation of partners is an increase in the coherence of sexual behavior and other behavioral patterns in males and females of $M$. spicilegus compared to M. musculus. Increasing of this indicator in a stable pair can be advantageous in terms of energy, since the males of $M$. spicilegus spend less effort on mating with the female compared with the males of M. musculus. Nevertheless, Zorenko and Atanasov (Zorenko, 2013; Zorenko \& Atanasov, 2018) analyzed the stereotype of copulatory behavior in a significant number of species of voles and concluded that the mating system does not directly affect the mating process itself, so there are no clear correlation between the breeding strategy and the copulatory behavior. According to these authors, the evolution of the copulatory stereotype largely reflects the phylogeny of the taxonomic group in voles and is less dependent on environmental factors.

In conspecific encounters $M$. musculus exhibited considerably lower level of affiliative behavior without certain sexual differences compared to M. spicilegus.
Studies of monogamous prairie voles indicate that females prolonged cohabitation with males and shared sexual experience within at list 24 hours lead to preferences of familiar males (Witt et al., 1990, Williams et al., 1992). As well studies provide evidence that males with experience of cohabitation and sexual behavior with single females engaged in more social contact with female than did sexually experienced males without prolonged cohabitation with single sexual partner (Witt et al., 1990). At the same time, females of Microtus ochrogaster which had both sexual and cohabitation experience with a male, spent more time in physical contact with familiar male, than females tested with an unfamiliar sexual partner (Carter et al., 1988). As we noted in the introduction, M. spicilegus is an optional monogamous species. Since affiliative behaviors in house mice realized predominately via direct physical contact and had the same reciprocal consequences in sexual partners of M. spicilegus, we suggest that enhancement in frequency and duration of affiliative behavior could lead to coordinating of activity of females and males of M. spicilegus. Perhaps a high level of affiliative behavior contributes to the establishment of long-term pair bonding between the male and the female in this species. In conspecific encounters, patterns of behavior facilitate the establishment of a pair bonding, namely, total mutual grooming and crowding (sitting together) was more often observed in males than in females, since they were more often the initiators of grooming than females. Male M. spicilegus exhibited this behavior significantly more often than male $M$. musculus. The similar results were obtained for two species of voles. Predominantly monogamous Microtus ochrogaster spending more time in body nosing and sitting in contact with each other than polygamous meadow vole $M$. pennsylvanicus (Dewsbury, 1987). In polygamous house mice such long-term pair bonding between the male and the female are not typical. Under semi-natural conditions Wolf (1985) demonstrated that mature males of $M$. musculus tended to set up their own defended areas, whereas females moved freely throughout the territories of neighboring males and chose high quality territories to deliver their litters. Besides, females mated significantly more often with males on whose territories they delivered their litters or males who defended high quality territories. Thus, females have opportunity to freely exercise choice of mate. The above-mentioned type of social structure excludes possibility of formation of a long-term social bonding between males and females. Patterns of behavior facilitate the establishment of a pair bonding, namely, mutual grooming and crowding (sitting together) were different in con- and heterospecific encounters. In heterospecific encounters this type of behavior observed only once, when $M$. musculus male groomed $M$. spicilegus females.

Previously we demonstrated that M. musculus and M. spicilegus clearly distinguish con- and heterospecific individuals by odor and prefer odor of conspecifics (Kotenkova et al., 1989b; Kotenkova \& Naidenko, 1999). Moreover, neural activation in receptor tissue of vomeronasal organ in response to conspecific receptive 
female odor stimulation was different in M. musculus and M. spicilegus males (Voznesenskaya et al., 2010). These findings clear indicate different chemical nature of the receptive female odor in these two species. We have every reason to suggest that namely the odor play a key role in the choice of sexual partner and causes the manifestation of sexual behavior in these species. For this reason, heterospecific potential sexual partners reject each other at stage of acquaintance.

Our results clearly demonstrate that not only the pattern of sexual behavior is important for the reproductive isolation, but also all types of behavioral interactions preceded copulation. Different stereotypes of mating behavior and different odors during the encounter of potential sexual partners can disturb the communicative process and prevent successful copulation.

In nature mound-building mice and house mice can live symbiotopically and inhabit the same habitats (Sokolov et al., 1990b). In our experiment aggression predominates in heterospecific encounters of males and females of $M$. musculus and M. spicilegus. This indicates that under natural conditions mating between $M$. musculus and M. spicilegus individuals may be highly unusual. The mutual aggression of the potential sexual partners of two sympatric species of mice can prevent the mating of heterospecific males and females and form one of the mechanisms of precopulatory isolation. In conspecific encounters females were more aggressive than males, but female $M$. musculus demonstrated elements of agonistic behavior significantly higher than $M$. spicilegus females. In presumably polygamous species Calomys musculinus Thomas, 1913 females are more aggressive than males in pair encounters (Laconi \& Castro-Vázquez, 1998).

In the laboratory, a stable pair in mound-building mice formed with difficulty and not in all cases due to the mutual aggressiveness of the partners. Couples of M. musculus are much easier to form, since males rarely exhibit agonistic behavior towards females. We consider ritualized aggression of females to the male as a form of selection of the most competitive males, especially in $M$. musculus. The males of $M$. musculus usually mated only after long unsuccessful attempts of mounts as a result of the ritualized aggressiveness which even receptive females demonstrate. Only persistent active males achieved success. In mound-building mice, males demonstrate the reciprocal aggression usually after weak aggression of the female. If the female exhibits high aggression for a long time, the male can manifest a sharp aggressive response: bites, attacks. Probably, in heterospecific encounters, such patterns of aggressive behavior completely prevented the mating of potential sexual partners.

Males and females of $M$. spicilegus exhibit agonistic behavior in groups towards strangers regardless of their gender (Sokolov et al., 1990b). However, the level of aggressive behavior depends on the season. In pair encounters of different variants, including males with anestrous females, the level of aggressive behavior was minimal in spring when mice leave mounds and begin to reproduce. Low level of aggres- sion continues throughout summer. Presumably, the level of aggressive behavior is a function of breeding activity and living conditions of mice in different seasons (Sokolov et al., 1990b). Our data indicate that the level of aggressive behavior of single male $M$. spicilegus towards females is not so high, if females are receptive, but still manifested.

Data from our current study and accumulated up-todate research show a complex nature of the discussed problem: measure of the competition of males for females, and therefore, the characteristics of sexual behavior associated with such a competition, depend on a number of factors. In particular, should be mentioned: the spatial-ethological structure of groupings, mating system, seasonality of reproduction and phylogeny features. Thus, all these factors should be taken into account, when interpreting the quantitative species-specific indicators of sexual and other forms of behavior.

ACKNOWLEDGMENTS. This research was supported by project 0109-2018-0074 "Ecological and evolutionary aspects of animal behavior and communication".

\section{References}

Abeelen J.H., van. 1966. Effects of genotype on mouse behavior // Animal Behaviour. Vol. 14. No. 2. P. 218-225.

Ambaryan A.B., Maltzev A.N. \& Kotenkova E.V. 2015. [Relationship between characteristics of sexual behavior and male sperm competitive ability in taxa of superspecies complex Mus musculus sensu lato] // Zhurnal Obshchei Biologii. Vol. 76. No.3. P. 212-224 [in Russian, with English summary].

Bardet J., Essen D.K., Feron C. \& Gouat P. 2007. Evaluation of the social bond: a new method tested in Mus spicilegus // Comptes Rendus Biologies. Vol. 330. No.11. P. 837-844.

Baudoin C., Busquet N., Dobson F.S., Cheusi G., Feron Ch., Durand J-L., Heth G., Patris B. \& Todrank J. 2005. Male-female associations and female olfactory neurogenesis with pair bonding in Mus spicilegus // Biological Journal of the Linnean Society. Vol.84. No. 3. P. 323-334.

Beach F.A. 1976. Sexual attractivity, proceptivity, and receptivity in female mammals // Hormones and Behavior. Vol. 7. No. 1. P. $105-138$.

Bronson F.H. 1979. The reproductive ecology of the house mouse // The Quarterly Review of Biology. Vol. 54. No. 3. P. 265-299.

Brotherton P.N.M. \& Komers P.E. 2003. Mate guarding and the evolution of social monogamy in mammals // Reichard U.H. \& Boesch C. (eds.). Monogamy: Mating Strategies and Partnerships in Birds, Humans and Other Mammals. Cambridge: Cambridge University Press. P. 42-58.

Bulatova N.Sh., Kotenkova E.V. \& Lyalyukhina S.I. 1986. [Fertility of hybrids and cytogenetic effect of hybrid dysgenesis in crossing in the mound-building mouse and laboratory mice] // Doklady Academii Nauk SSSR. Vol. 288. No. 4. P. 1018-1020 [in Russian, with English summary].

Carlsen M. 1993. Migrations of Mus musculus musculus in Danish farmland // Zeitschrift fur Saugetierkunde. Vol. 58. No. 3. P. $172-180$. 
Carter S., Vries C. \& Getz L. 1995. Physiological substrates of mammalian monogamy: the prairie vole model // Neuroscience \& Biobehavioral Reviews. Vol.19. No.2. P.303-314.

Carter C.S., Whitt M.D., Thompson G. \& Carlstead K. 1988. Effects of hormonal, sexual, and social history on mating and pair bonding in prairie voles // Physiology and Behavior. Vol.44. No.6. P.691-697.

Chatterjee S. \& Singh B.N. 1989. Sexual isolation in Drosophila // Indian Review of Life Science. Vol.9. P.101-135.

Chevret P., Veyrunes F. \& Britton-Davidian J. 2005. Molecular phylogeny of the genus Mus (Rodentia: Murinae) based on mitochondrial and nuclear data // Biological Journal of the Linnean Society. Vol.84. No.3. P.417-427.

Clutton-Brock T.H., Guinness F.E. \& Albon S.D. 1982. Red Deer: Behavior and Ecology of Two Sexes. Edinburgh: Edinburgh University Press. 378 p.

Clutton-Brock T.H. \& Isvaran K. 2006. Paternity loss in contrasting mammalian societies // Biological Letters. Vol.2. No.4. P.513-516.

Crowcroft P. 1954. Mouse research in Suffolk // Transactions of the Suffolk Natural Society. Vol.8. P.185-187.

Crowcroft P. 1955. Social organization in wild mouse colonies // The British Journal of Animal Behaviour. Vol.3. No.1. P.1-36.

Crowcroft P. \& Rowe F.P. 1963. Social organization and territorial behavior in the wild house mouse (Mus musculus L.) // Proceedings of the Zoological Society of London. Vol.140. No.3. P.517-531.

Davis D.E. 1958. The role of density in aggressive behaviour in house mice // Animal Behaviour. Vol.6. No.3-4. P.207-210.

Dewsbury D.A. 1981. On the function of the multiple-intromission, multiple-ejaculation copulatory patterns of rodents // Bulletin of the Psychonomic Society. Vol.18. No.4. P.221-223.

Dewsbury D.A. 1987. The comparative psychology of monogamy // Leger D.W. (ed.). Comparative Perspectives in Modern Psychology. Nebraska Symposium on Motivation. Vol.35. Nebraska: Nebraska University Press. P.1-50.

Dewsbury D.A., Oglesby J.M., Sandra L., Shea S.L., James L. \& Connor J.L. 1979. Inbreeding and copulatory behavior in house mice: a further consideration // Behavior Genetics. Vol.9. No.3. P.151-163.

Dixon A.F. 2012. Primate Sexuality. Comparative Studies of the Prosimians, Monkeys, Apes and Humans. New York: Oxford Academic Press. 742 p.

Dobson F.S. \& Baudoin C. 2002. Experimental tests of spatial association and kinship in monogamous mice (Mus spicilegus) and polygynous mice (Mus musculus domesticus) // Canadian Journal of Zoology. Vol.80. No.6. P.980-986.

Dobson F.S., Way B.M. \& Baudoin C. 2010. Spatial dynamics and the evolution of social monogamy in mammals // Behavioral Ecology. Vol.21. No.4. P.747-752.

Emlen S.T. \& Oring L.W. 1977. Ecology, sexual selection, and the evolution of mating systems // Science. Vol.197. No.4300. P.215-223.

Estep D.Q., Lanier D.L. \& Dewsbury D.A. 1975. Copulatory behavior and nest building behavior of wild house mice (Mus musculus) // Animal Learning and Behavior. Vol.3. No.4. P.329-336.

Feron C. \& Gouat P. 2007. Paternal care in the mound-building mouse reduces inter-litter intervals // Reproduction, Fertility and Development. Vol.19. No.3. P.425-429.
Fitzgerald R.W. \& Madison D.M. 1983. Social organization of a free-ranging population of pine voles, Microtus pinetorum // Behavioral Ecology and Sociobiology. Vol.13. No.3. P.183-187.

Frynta D., Slábová M. \& Vohralík V. 2009. Why do male house mice have such small testes? // Zoological Science. Vol. 26. No.1. P.17-23.

Frynta D., Volfová R., Franková-Nováková M. \& Stejskal V. 2010. Oestrous females investigate the unfamiliar male more than the familiar male in both commensal and non-commensal populations of house mice // Behavioural Processes. Vol.83. No.1. P.54-60.

Getz L.L., Hofmann J.E. \& Carter C.S. 1987. Mating system and population fluctuations of the prairie vole, Microtus ochrogaster // American Zoologist. Vol.27. No.3. P.909-920.

Gouat P. \& Feron C. 2005. Deficit in reproduction in polygynously mated females of the monogamous mound-building mouse Mus spicilegus // Reproduction, Fertility and Development. Vol.17. No.6. P.617-623.

Gouat P., Katona K. \& Poteaux C. 2003. Is the socio-spatial distribution of mound-building mice, Mus spicilegus, compatible with a monogamous mating system? // Mammalia. Vol.67. No.1. P.15-24.

Grant E.C. \& Mackintosh I.H. 1963. A comparison of social posture of some common laboratory rodents // Behavior. Vol.21. No.3-4. P.246-259.

Hamar M. \& Sutova-Hamar M. 1969. Estimation of rodent home ranges in different agrosystems // Energy Flow Through Small Mammal Population. Proceedings of IBP Meeting on Secondary Productivity in Small Mammal Populations. Oxford. P.99-109.

Harcourt A.H., Harvey P.H., Larson S.G. \& Short R.V. 1981. Testis weight, body weight and breeding system in primates // Nature. Vol.293. No.5827. P.55-57.

Harvey P.H. \& Harcourt A.H. 1984. Sperm competition, testes size, and breeding systems in primates // Smith R.L. (ed.). Sperm Competition and the Evolution of Animal Mating Systems. New York: Academic Press. P.589-600.

Heske E.J. \& Ostfeld R.S. 1990. Sexual dimorphism in size, relative size of testes, and mating systems in North American voles // Journal of Mammalogy. Vol. 71. No. 4. P. 510-519.

Hurst J.L. 1986. Mating in free-living wild house mice (Mus domesticus) // Journal of Zoology. Vol. 210. No. 4. P. 623-628.

Johnson Z. \& Young L.J. 2015. Neurobiological mechanisms of social attachment and pair bonding // Current Opinion in Behavioral Sciences. Vol.3. P.38-44.

Iossa G., Soulsbury C.D., Baker P.J. \& Harris S. 2008. Sperm competition and the evolution of testes size in terrestrial mammalian carnivores // Functional Ecology. Vol. 22. No.4. P.655-662.

Isvaran K. \& Clutton-Brock T. 2007. Ecological correlates of extra-group paternity in mammals // Proceedings of the Royal Society of London, B. Vol.274. No.1607. P.219-224.

Kenagy G.J. \& Trombulak S.C. 1986. Size and function of mammalian testes in relation to body size // Journal of Mammalogy. Vol.67. No.1. P.1-22.

Kotenkova E.V. 2014. A comparative analysis of ethological and physiological mechanisms of precopulatory isolation // Biology Bulletin Reviews. Vol.134. No.5. P.488-518. 
Kotenkova E.V. \& Munteanu A.I. 2006. [A comparative analysis of the spatial-ethological population structure of different species of house mice related to their mode of life] // Uspekhi Sovremennoi Biologii. Vol.126. No.5. P.513-528 [in Russian, with English summary].

Kotenkova E.V. \& Naidenko S.V. 1999. Discrimination of con- and heterospecific odors in different taxa of the Mus musculus species group: olfactory cues as precopulatory isolating mechanism // Johnston R.E., Muller-Schwarze D. \& Sorensen P. (eds.). Advances in Chemical Communication in Vertebrates. New York: Plenum Press. P.299-308.

Kotenkova E.V., Osipova O.V. \& Lyalyukhina S.I. 1989a. Behavioral elements and seasonal changes of behavior in mound-building mice (Mus hortulanus Nordm.) // Sokolov V.E., Kotenkova E.V., Krasnov B.R. \& Meshkova N.N. (eds.). [The House Mouse]. Moscow: Institute of Evolutionary Animal Morphology and Ecology. P.256-272 [in Russian, with English summary]

Kotenkova E.V., Osadchuck A.V. \& Lyalyukhina S.I. 1989b. Precopulatory isolating mechanisms between the house and mound-building mouse // Acta Theriologica. Vol.34. No.22. P.315-324.

Krasnov B.R. \& Chochlova J.S. 1994. [Spatial ethological structure of groups] // Kotenkova E.V. \& Bulatova N.Sh. (eds.). [The House Mouse: Origin, Distribution, Systematics, Behaviour]. Moscow: Nauka. P.188-214 [in Russian].

Laconi M.R. \& Castro-Vázquez A. 1998. Aggressive interactions during mating encounters in the corn mouse, Calomys musculinus (Muridae, Sigmodontinae) // Mastozoología Neotropical. Vol.5. No.1. P.21-28.

Levine L., Barsel G.E. \& Diakow G.A. 1966. Mating behavior of two inbred strains of mice // Animal Behaviour. Vol.14 No.1. P.1-6.

Lidicker W.L. 1976. Social behavior and density regulation in house mice living in large enclosure // Journal of Animal Ecology. Vol.45. No.3. P.677-697.

Lieberwirth C. \& Wang Z. 2016. The neurobiology of pair bond formation, bond disruption, and social buffering // Current Opinion in Neurobiology. Vol.40. P. 8-13.

Lloyd I.A. 1975. Social structure and reproduction in two free-growing populations in house mice (Mus musculus) // Animal Behaviour. Vol.23. No.2. P.413-424.

Mackintosh J.H. 1981. Behaviour of house mouse // Symposia of the Zoological Society of London. Vol.47. P.337-365.

Mangels R., Tsung K., Kwan K. \& Dean M.D. 2016. Copulatory plugs inhibit the reproductive success of rival males // Journal of Evolutionary Biology. Vol. 29. No.11. P.2289-2296.

Manno T.G. \& Dobson F.S. 2008. Why are male Columbian ground squirrel's territorial? // Ethology. Vol.114. No.11. P.1049-1060

Manno T.G., Nesterova A.P., Debarbieri L.M., Kennedy S.E., Wright K.S. \& Dobson F.S. 2007. Why do male Columbian ground squirrels give a mating call? // Animal Behaviour. Vol.74. No.5. P.1319-1327.

McGill T.E. 1962. Sexual behavior in three inbred strains of mice // Behaviour. Vol.19. No.4. P.341-350.

McGill T.E. \& Ranson T.W. 1968. Genotypic change affecting conclusions regarding the mode of inheritance of elements of behavior // Animal Behaviour. Vol.16. No.1. P.88-91.

Mezhzherin S.V. 1994. [Taxonomy and modern views on the system of Palaearctic house mice] // Kotenkova E.V.
\& Bulatova N.Sh. (eds.). [The House Mouse: Origin, Distribution, Systematics, Behaviour]. Moscow: Nauka. P.15-36 [in Russian].

Montoto L.G., Magana C., Tourmente M., Martin-Coello J., Crespo C., Luque-Larena J.J., Gomendio M. \& Roldan E.R.S. 2011. Sperm competition, sperm numbers and sperm quality in muroid rodents // PLoS ONE. Vol.6. No.3. e18173.

Mosig D.W. \& Dewsbury D.A. 1976. Studies of the copulatory behavior of house mice (Mus musculus) // Behavioral Biology. Vol.16. No.4. P.463-473.

Naumov N.P. 1940. [Ecology of mound-building mouse Mus musculus hortulanus Nordm.] // Trudy Instituta Evolutsionnoi Morfologii Akademii Nauk SSSR. Vol.3. P.33-76 [in Russian, with English summary].

Nelson J.F., Felicio L.S., Randall P.K., Sims C. \& Finch C.E. 1982. A longitudinal study of estrous cyclicity in aging C57BL/6J mice: I. Cycle frequency, length and vaginal cytology // Biology of Reproduction. Vol.27. No.2. P.327-39.

Noordwijk M.A., van \& Schaik C.P., van. 2004. Sexual selection and the careers of primate males: paternity concentration, dominance-acquisition tactics and transfer decisions // Kappeler P.M. \& Schaik C.M., van. (eds.). Sexual Selection in Primates: New and Comparative Perspectives. Cambridge: Cambridge University Press. P.208-221.

Patris B. \& Baudoin C. 1998. Female sexual preferences in Mus spicilegus and Mus musculus domesticus: the role of familiarization and sexual experience // Animal Behaviour. Vol.56. No.6. P.1465-1470.

Patris B. \& Baudoin C. 2000. A comparative study of parental care between two rodent species: implications for the mating system of the mound-building mouse Mus spicilegus // Behavioural Processes. Vol.51. No.1-3. P.35-43.

Patris B., Gouat P., Jacquot C., Christophe N. \& Baudoin C. 2002. Agonistic and sociable behaviors in the mound-building mouse, Mus spicilegus, a comparative study with Mus musculus domesticus // Aggressive Behavior. Vol.28. No.1. P.75-84.

Pelikán J. 1981. Patterns of reproduction in the house mouse // Symposia of the Zoological Society of London. Vol.47. P.205-229.

Pisareva M.E. 1948. [Ecology and systematic of mound-building mouse] // Sbornik Rabot Biologicheskogo Fakulteta Dnepropetrovskogo Gosudarstvennogo Universiteta: Uchenye Zapiski. Vol.32. P.68-71 [in Russian].

Pitcher T.E., Dunn P.O. \& Whittingham L.A. 2005. Sperm competition and the evolution of testes size in birds // Journal of Evolutionary Biology. Vol.18. No.3. P.557-567.

Poteaux C., Busquet N., Gouat P., Katona K. \& Baudoin C. 2008. Socio-genetic structure of mound-building mice, Mus spicilegus, in autumn and early spring // Biological Journal of the Linnean Society. Vol.93. No.4. P.689-699.

Ptacek M.B. 2000. The role of mating preferences in shaping interspecific divergence in mating signals in vertebrates // Behavioral Processes. Vol.51. No.1-3. P.111-134.

Ramm S.A. \& Stockley P. 2007. Ejaculate allocation under varying sperm competition risk in the house mouse, Mus musculus domesticus // Behavioral Ecology. Vol.18. No.2. P.491-495.

Roemer G.W., Smith D.A., Garcelon D.K. \& Wayne R.K. 2001. The behavioral ecology of the island fox (Urocyon littoralis) // Journal of Zoology. Vol.255. No.1. P.1-14. 
Schubert M., Schradin C., Rödel H.G., Pillay N. \& Ribble D.O. 2009. Male mate guarding in a socially monogamous mammal, the round-eared sengi: on costs and trade-offs // Behavioral Ecology and Sociobiology. Vol. 64. No. 2. P. 257-264.

Simeonovska-Nikolova D.M. 2007. Spatial organization of the mound-building mouse, Mus spicilegus in the region of the northern Bulgaria // Acta Zoologica Sinica. Vol. 53. No. 1. P. 22-28.

Simeonovska-Nikolova D.M. 2012. Neighbour relationships and spacing behaviour of mound-building mouse, Mus spicilegus (Mammalia: Rodentia) in summer // Acta Zoologica Bulgarica. Vol. 64. No. 2. P. 135-143.

Singleton G.R. \& Hay D.A. 1983. The effect of social organization on reproductive success and gene flow in colonies of wild house mice, Mus musculus // Behavioral Ecology and Sociobiology. Vol. 12. No.1. P. 49-56.

Shuster S.M. \& Wade M.J. 2003. Mating Systems and Strategies. Princeton: Princeton University Press. 552 p.

Smadja C. \& Butlin R.K. 2009. On the scent of speciation: the chemosensory system and its role in premating isolation // Heredity. Vol. 102. No. 1. P. 77-97.

Sokolov V.E., Zagoruiko N.V., Kotenkova E.V. \& Lyalyukhina S.I. 1988. [Comparative analysis of behavior of house (Mus musculus musculus) and mound-building (Mus hortulanus) mice] // Zoologicheskii Zhurnal. Vol. 67. No. 8. P. 1214-1224 [in Russian, with English summary].

Sokolov V.E., Chernyshev M.K., Voznessenskaya V.V. \& Zinkevich E.P. 1990a. [A biorhytmic approach to evaluation of the effect of olfactory cues on reproductive state of the Norway rat (Rattus norvegicus)] // Izvestiya Akademii Nauk SSSR. Seriya Biologicheskaya. No. 2. P. 248-260 [in Russian, with English summary].

Sokolov V.E., Kotenkova E.V. \& Lyalyukhina S.I. 1990b. [Biology of House and Mound-building Mice]. Moscow: Nauka. 208 p. [in Russian, with English summary].

Sokolov V.E., Kotenkova E.V. \& Mikhailenko A.G. 1998. Mus spicilegus. Mammalian Species. No. 592. P. 1-6.

Stopka P. \& Macdonald D.W. 1998. Signal interchange during mating in the wood mouse Apodemus sylvaticus: The concept of active and passive signaling // Behaviour. Vol. 135. No. 2. P. 231-249.

Stopka P. \& Macdonald D.W. 1999. The market effect in the wood mouse Apodemus sylvaticus: Selling information on reproductive status // Ethology. Vol. 105. No. 11. P. 969-982.

Verrell P.A. 1999. Geographical variation in sexual behavior: Sex signals and speciation // Foster S.A. \& Endler J.A. (eds.). Geographic Variation in Behavior. Oxford: Oxford University Press. P. 262-286.
Voznesenskaya A.E., Ambaryan A.V., Klyuchnikova M.A., Kotenkova E.V. \& Voznessenskaya V.V. 2010. Mechanisms of reproductive isolation in house mouse superspecies complex Mus musculus s. lato: from behaviour to receptors // Doklady Biological Sciences. Vol. 435. No. 3. P. 418-420.

Walkowa W., Kotenkova E., Adamczyk K. \& Barkowska M. 1998. Behavior of house mice in semi-natural conditions: influence of spatial separation and population size // Acta Theriologica. Vol. 43. No. 3. P. 241-254.

Waterman J. 2007. Male mating strategies in rodents // Wolff J.O. \& Sherman P.W. (eds.). Rodent Societies: an Ecological and Evolutionary Perspective. Chicago: University of Chicago Press. P. 27-41.

Williams J.R., Catania K. \& Carter C.S. 1992. Development of partner preferences in female prairie voles (Microtus ochrogaster): the role of social and sexual experience // Hormones and Behavior. Vol. 26. No. 3. P. 339-349.

Witt D.M., Carter C.S., Carlstead K. \& Read L.D. 1988. Sexual and social interactions preceding and during male induced oestrus in prairie voles, Microtus ochrogaster // Animal Behaviour. Vol. 36. No. 5. P. 1465-1471.

Witt D.M., Carter C.S., Chayer R. \& Adams K. 1990. Patterns of behaviour during postpartum oestrus in prairie voles, Microtus ochrogaster // Animal Behaviour. Vol. 39. No. 3. P. $528-534$.

Wolf R.J. 1985. Mating behaviour and female choice: their relation to social structure in wild caught house mice (Mus musculus) housed in semi-natural environment // Journal of Zoology. Vol. 207. No. 1. P. 43-51.

Young K.A., Gobrogge K.L., Liu Y. \& Wang Z. 2011. The neurobiology of pair bonding: Insights from a socially monogamous rodent // Frontiers in Neuroendocrinology. Vol. 32. No. 1. P. 53-69.

Zorenko T.A. 2013. [Social Voles of the Subgenus Sumeriomys: Systematics, Biology and Behavior]. Saarbrücken: Palmariun Academic Publishing. 541 p. [in Russian].

Zorenko T. \& Atanasov N. 2017. Patterns of behaviour as an evidence for the taxonomical status of Lasiopodomys (Stenocranius) gregalis (Pallas, 1779) (Rodentia: Arvicolinae) // Acta Zoologica Bulgarica. Supplement No. 8. P. 189-197.

Zorenko T. \& Atanasov N. 2018. Copulatory behavior supports a new insight into taxonomic status of root vole Alexandromys oeconomus (Rodentia, Arvicolinae) // Russian Journal of Theriology. Vol. 17. No. 1. P. 48-57.

Zorenko T. A. \& Malygin V.M. 1984. [Effects of ethological reproductive isolation mechanisms for the hybridization of three species of common voles group arvalis (Microtus, Cricetidae)] // Zoologicheskii Zhurnal. Vol. 63. No. 7. P. 1072-1983 [in Russian, with English summary]. 